Kaltenborn, Bruno / Krug, Gerhard / Rudolph, Helmut/Weinkopf, Claudia / Wiedemann, Eberhard (2005): Evaluierung des arbeitsmarktpolitischen Sonderprogramms CAST. Endbericht des Forschungsverbundes, BMWA-Forschungsbericht, Nr. 552, Berlin

Kaltenborn, Bruno/Schiwarov, Julia/Wielage, Nina (2006): Arbeitsanreize im Niedriglohnbereich - ein internationaler empirischer Überblick, Beiträge zur Wirtschaftsforschung und Politikberatung, Nr. 3I, Berlin

Sinn, Hans-Werner / Holzner, Christian / Meister, Wolfgang/ Ochel, Wolfgang/Werding, Martin (2006): Aktivierende Sozialhilfe 2006: Das Kombilohn-Modell des ifo Instituts, in: ifoSchnelldienst, Jg. 59, H. 2, S. 3-24

Spermann, Alexander (2006): Mehr Druck, mehr Anreiz. Wie ein erfolgreiches KombilohnModell aussehen könnte, in: Die ZEIT vom I9.0I.2006

Weinkopf, Claudia (2006a): Kombilöhne - Kein Patentrezept für den Arbeitsmarkt, in: Soziale Sicherheit, Jg. 55, H. 3, S. 98-IO2

Weinkopf, Claudia (2006b): Was bringen Kombilöhne?, in: Sterkel, Gabriele/ Schulten, Thorsten/Wiedemuth, Jörg (Hg.), Mit Mindestlöhnen gegen Sozialdumping, Hamburg, S. $80-103$

\title{
Inequality and Efficiency - Does a Wider Spread of Wages Raise Employment? Ronald Schettkat*
}

\section{A Unified Theory?}

The assumed trade-off between efficiency and equality is deeply engraved in the minds of many economists. Applied to labor markets this assertion says that a wider dispersion of wages raises employment. Welch (1999), addressing the American Economic Association in the Richard T. Ely Lecture`, praises the beauty of an economy with high inequality, and sociologists claim that inequality is the price for freedom (Dahrendorf 2006). Why should a wider wage dispersion improve employment? Many hypotheses have been forwarded:

I. wages equal workers' marginal productivity and therefore a wider dispersion of wages allows for an integration of the less productive workers;

2. workers of all ranks are - like tournament players - motivated by the high rewards for the winner, i.e. the top earners;

3. all western economies were hit by the same shocks (skill-biased technological change, globalization), which are disadvantageous for less skilled workers and result in a wider

* University of Wuppertal. 
dispersion of wages in countries with flexible wage structures but in unemployment in countries with inflexible wage structures (the stwo sides of the same coin hypothesis, Krugman 1994).

But it is unclear whether declining demand for less skilled workers erodes their wages or whether wage compression extinguishes demand for less skilled labor. Among the first U.S. economists who discussed the rising dispersion of wages were Harrison / Bluestone (198I) who emphasized the changing industry structure (declining manufacturing and rising services) as the major cause for rising wage inequality in America. The industry structure, however, turned out not to be the driving force behind the rising wage inequality in the U.S. The image of services as $\gg$ McDonald jobs was oversimplified since the sector includes also high-paid `McKinsey` jobs (Freeman / Schettkat 1998). Contrary to common believes, employment growth in the USA was not concentrated in the low skill sector, here demand declined substantially, but rather in higher skills.

"The sizeable reductions in pay for the less skilled in the USA have not been sufficient to maintain their employment; have impoverished them and their families; and arguably contributed to the decision of many of them to engage in crime." (Freeman 1995: 72)

Siebert (1997: 45) in a widely recognized article in the Journal of Economic Perspectives thought he proves the assertion that a wider wage dispersion improves employment especially at the low end of labor market when he wrote:

"A country which institutionally prohibits flexible wages at the lower end can be expected to have a low percentage of employment in low-paid jobs. This is exactly what can be observed. Defining low-paid workers as those who earn less than twothirds of the median wage, the percentage of low-paid workers in total employment varies noticeably with the dispersion of earnings, from 5.2 percent in Sweden to 25 percent in the U.S. (Belgium 7.2, Netherlands II.9, Italy I2.5, Germany 13.3, France 13.3, United Kingdom 19.6; OECD 1996, Table 3.2)."

Well, Sweden is not known for low employment rates, and what seems to be a proof for Siebert is just a tautology: below a certain value are, of course, less persons in a narrower than in a wider distribution, as Krueger / Pischke (1997) reminded Siebert. Why does Siebert, a former member of the German Sachverständigenrat (Council of Economic Advisors) and former president of the Kiel Institute for the World Economy, believe that he can present such a statement to an international audience of professional economists? Either he was not aware of the tautology in his statement or he thought he could get through with it. In both cases it seems to be the overly strong orientation on the perfect market model which leads researchers to be immoderately sketchy with empirics. Allowing for a richer set of theoretical models, for example monopsony models (see especially Manning 2003), will force analysts to be more careful in empirical work.

Also for the OECD simple cross-country correlations seem to be sufficient to confirm prejudices, and crude analysis seems to overrule detailed micro-econometric anal- 
ysis: On an aggregate level the OECD (2004) finds a significant negative correlation between wage dispersion (measured by the $\mathrm{D}_{9} / \mathrm{D}_{\mathrm{I}}$ ratio $^{\mathrm{I}}$ of the wages of men employed fulltime) and unemployment and a significant positive correlation between the D9/ Di-ratio and employment-population rates. Similar the OECD finds a negative correlation between the D5/DI-ratio for full-time male workers and the employment-population rates for subgroups assumed to be sensitive to wage dispersion, i.e. women, younger and older workers (for similar results see also Bertola et al. 2002). Furthermore the apparent trade-off between a strong employment performance and a more equal distribution of earnings appears to have worsened, consistent with relative labor demand having shifted towards high-skilled workers (OECD 2004: 129). The OECD mentions micro-econometric studies which do not confirm the cross-section results (as it is not in line with an earlier OECD [I997] study):

"Indeed, it appears that the majority of international studies using micro data to test whether the relative employment performance of low-skilled workers was worse in countries where the wage premium for skill was more rigid have not verified this thesis (e.g. Card et al., 1999; Freeman / Schettkat, 2000; Krueger / Pischke, 1997; Nickell / Bell, 1995).«(OECD 2004: 142)

Neoclassical theory predicts a downward sloping labor demand curve derived from diminishing marginal productivity of labor. In such a model any restriction of wages at the lower end will cost jobs if wages are set above the market clearing level. Therefore, for many neoclassical economists unemployment can only exist if ırigidities in labor markets prevent a flexible wage response, which otherwise would clear the market. More employment requires lower wages or in other words: workers can price themselves into employment. Minimum wages - be they constituted by law, derived from transfer programs, or collectively bargained - will limit employment opportunities, they are poison for jobs as a wide range of economists even at the more progressive end of the profession believe.

\section{Facts}

However, widely accepted theory is one thing, but positive economics is another. What are the results of empirical studies on the employment effects of minimum wages? Most famous is the work by Card/Krueger (1995), who applied sophisticated quasi-experimental sampling techniques to evaluate the effect of a rise in the legal minimum wage in New Jersey, USA. An increase of the minimum wage of roughly 20 percent did not lead to the predicted decline in employment although a substantial number of workers received formerly wages below the new minimum. What a wonderful world it would be? Of course, nobody argues that wages and wage structures do not affect employment, but there is

I The D9/Di-ratio shows the wage of the top ten percent wage earners relative to the wage of the ten percent workers with the lowest wage. The D5/Di-ratio shows the median wage relative to the wage of the ten percent workers with the lowest wage. 
sa range of indeterminacy‘. "The typical employer in an unorganized labor market is by no means a pure competitor facing market wages which he cannot alter " (Bronfenbrenner I956: 578). The debates following the Card/Krueger analysis changed the views of the U.S. economics profession substantially: in 199063 percent of the American economics professors thought that a higher legal minimum wage will raise unemployment among young and unskilled workers; in 2000 this number shrunk to 46 percent, a 17 percentage point decline in ten years (Fuller/Geide-Stevenson 2003)! Not many economists can claim that their studies changed the minds of the scientific community that strongly as the Card/ Krueger minimum wage analysis did.

In an international comparison between the U.S., France, and Canada, Card et al. (I996) found the expected pattern of wage dispersion. The highest values were computed for the U.S., medium range values for Canada and the lowest for France, but they failed to establish the corresponding evidence in employment patterns. Freeman/Schettkat (I999) failed to establish the relationship between relative wages and employment in a comparative U.S.-German analysis based on the Structural German American Database. Similarly, Krueger / Pischke (1997) could not establish evidence for the wage compression hypotheses for the same countries but based on different data. Freeman / Schettkat (I999) also failed to establish evidence for the integration of low-skilled workers into employment claimed by proponents of flexible wages. If flexible wages allow for the integration of less-skilled workers into employment, one expects the skill structure of the employed to be roughly similar to that of the unemployment because unemployment should only be frictional. In the U.S., therefore, the difference in skills between employed and unemployed workers should be small whereas the wage compression hypothesis predicts a substantial difference for Germany. In the latter, it is the standard argument that the less skilled workers are excluded from employment because their reservation wages are blamed to be higher than their productivity. Based on so-called literacy scores from the International Adult Literacy Survey (OECD 1997), Freeman / Schettkat (200I) found, however, that the skill median of the employed is about 290 (on a scale from o to 500) in both countries, but that the skill median of the unemployed is 277 in Germany and 257 in the U.S. This result is in stark contrast to the prediction of the wage compression hypothesis.

Furthermore, Germany, which was the example for a country with an overly rigid wage structure for a long time, experienced an explosion of wage inequality. According to EU analysis (European Commission 1998 and 2005) the D9/DI-ratio for Germany rose from 2.5I in 1995 in only seven years to 3.15 in 2002. A 40 percent increase, putting Germany next to Britain, which was so far leading wage inequality in Western Europe. With respect to the lower end, represented by the D5/Di-ratio, Germany achieves wage dispersion unique in Western Europe and higher only in the East European countries which joined the EU recently (e.g., Poland, Estonia etc.). In contrast to former analyses the wage dispersion at the lower end of the pay scale seems to be particularly high in Germany. Former analyses (most prominent Blau/Kahn 1996) found especially low values for wage dispersion in Germany represented by the D5/DI-ratio. Ironically, the increase in wage dispersion in Germany occurred simultaneously to the rise of unemployment among less skilled 
workers. An obvious argument against these figures is the difference in wages between west and east Germany, but the 2002 D9/ Di values also occur in many western Länder, and in Hamburg the value is even exceeded. In a comparative German-American analysis Möller (2005) finds a wider D5/Di wage spread for women in Germany uncontrolled for skills. Given that skill differentials are larger in the U.S. than in Germany (Freeman / Schettkat 200I), the Möller result again shows that the empirical basis for the wage compression hypothesis as the major cause for high German unemployment is flawed.

Most analyses on the rising wage dispersion has been performed in the U.S. and the majority tended to emphasize skill-biased technological change as the main cause (e.g., Katz / Murphy 1992, Katz / Autor 1999). In recent years, however, institutional factors seem to be favored. Card / DiNardo (2002) criticize the sstandard Katz / Murphy method, which interprets shifts in demand functions as technological change, and they even ask whether it is stechnology or tautology‘. In their view technological change has got too much weight in the past and they point to institutional changes (minimum wages, decline in unionization) as the main cause for changing wage dispersion in the U.S. DiNardo et al. (I995) studied the impact of the declining real minimum wage in the U.S. during the I980s using kernel density functions. During the Reagan administration the U.S. Federal nominal minimum wage was frozen, which resulted in a stretched left tail of the wage distribution. When the minimum wage was raised the distribution got compressed but the authors did not find any evidence that declining real minimum wages were job-creating nor that increases in the minimum were job-damaging. The distributional effects of changes in the minimum wages seem to be strong, but employment effects seem to be limited. Also a recent study by DewBecker/Gordon (2005) argues that skill-biased technological change cannot explain the enormous concentration of income growth among the highest income earners in the U.S. The only group with above the average income growth from 1997 to $200 \mathrm{I}$ was the top ten percent, but within this group 50 percent of the increase went to the top one percent.

\section{Conclusions}

In summary most recent analyses ascribe a big role for rising wage dispersion to institutional variables and labor demand shifting away from low-skilled labor. These are the empirical observable trends, but it remains speculation whether a wider dispersion of wages would create jobs. Many economists in Germany seem to be unaware of the enormous rise in German wage dispersion, which reaches according to some analyses U.S. dimensions. Any explanation of German unemployment with an overly compressed wage structure seems to be at odds with the facts. Probably it is difficult to give up long-believed models, but one should recall the flexibility of John Maynard Keynes who initially argued in line with neoclassical production theory that higher employment requires lower real wages, but got convinced by two young economists, Dunlop (1938) and Tarshis (1939), who showed that productivity rises in tandem with employment if the economy moves out of a recession.

»When the facts change, I change my mind. What do you do, Sir?» (Keynes) 


\section{References}

Bertola, Giuseppe/Blau, Francine/Kahn, Lawrence (2002): Labor Market Institutions and Demographic Employment Patterns, NBER Working Paper, No. 9043, Cambridge, MA: National Bureau of Economic Research

Blau, Francine/Kahn, Lawrence (1996): International Differences in Male Wage Inequality: Institutions versus Market Forces, in: Journal of Political Economy, Vol. I04, No. 4, pp. 79I-837

Bronfenbrenner, Martin (1956): Potential Monopsony in the Labor Market, in: Industrial and Labor Relations Review, Vol. 9, No. 4, pp. 577-588

Card, David/DiNardo, John (2002): Skill Biased Technological Change and Rising Wage Inequality: Some Problems and Puzzles, NBER Working Paper, No. 8769, Cambridge, MA: National Bureau of Economic Research

Card, David / Kramarz, Francis / Lemieux, Thomas (1996): Changes in the Relative Structure of Wages and Employment: A Comparison of the United States, Canada and France, NBER Working Paper, No. 5487, Cambridge, MA: National Bureau of Economic Research

Card, David / Krueger, Alan (1995): Myth and Measurement: The New Economics of the Minimum Wage, Princeton: Princeton University Press

Dahrendorf, Ralf (2006): Inequality and Discontent, Project Syndicate, www.project-syndicate. org

Dew-Becker, Ian L./Gordon, Robert J. (2005).: Where Did the Productivity Growth Go? Inflation Dynamics and the Distribution of Income, NBER Working Paper, No. II842, Cambridge, MA: National Bureau of Economic Research

DiNardo, John / Fortin, Nicole M. / Lemieux, Thomas (1995): Labor Market Institutions and the Distribution of Wages, I973-I992: A Semiparametric Approach, NBER Working Paper, No. 5093, Cambridge, MA: National Bureau of Economic Research

Dunlop, John (1938): The Movement of Real and Money Wages, in: Economic Journal, Vol. 48, No. I9I, pp. 4I3-433.

European Commission (1998): Employment in Europe Report 1998, Employment and Social Affairs, Brussels

European Commission (2005): Employment in Europe Report 2005, Employment and Social Affairs, Brussels

Freeman, Richard (1995): The Limits of Wage Flexibility to Curing Unemployment, in: Oxford Review of Economic Policy, Vol. II, No. 4, pp. 63-72

Freeman, Richard/Schettkat, Ronald (200I): Skill Compression, Wage Differentials, and Employment: Germany vs the US, in: Oxford Economic Papers, Vol. 53, No. 3, pp. 582-603

Freeman, Richard/Schettkat, Ronald (1999): Differentials in Service Industry Employment Growth: Germany and the US in the Comparable German American Structural Database, in: European Commission, Report, Brussels

Freeman, Richard / Schettkat, Ronald (1998): From McDonalds to McKinsey: Comparing German and US Employment and Wage Structures, Leverhulme II Conference, Institute of Economics and Statistics, Oxford 
Fuller, Dan / Geide-Stevenson, Doris (2003): Consensus Among Economists Revisited, in: Journal of Economic Education, Vol. 34, No. 4, pp. 369-387

Harrison, Bennett/ Bluestone, Barry (I98I): The Great U-Turn. Corporate Restructuring and the Polarizing of America, New York: Basic Books

Katz, Lawrence/ Autor, David (1999): Changes in the Wage Structure and Earnings Inequality, in: Ashenfelter, Orley/ Card, David (eds.), Handbook of Labor Economics, Vol. 3A, Chapter 26, Amsterdam: Elsevier, pp. 1463-1555

Katz, Lawrence/Murphy, Kevin (1992): Changes in Relative Wages 1963-1987: Supply and Demand Factors, in: Quarterly Journal of Economics, Vol. I07, No. I, pp. 35-78

Krueger, Alan / Pischke, Jörn-Steffen (1997): Observations and Conjectures on the US Employment Miracle, NBER Working Paper, No. 6I46, Cambridge, MA: National Bureau of Economic Research

Krugman, Paul (1994): Past and Prospective Causes of High Unemployment, in: Economic Review, Vol. 79, No. 4, pp. 23-43

Manning, Alan (2003): Monopsony in Motion: Imperfect Competition in Labor Markets, Princeton: Princeton University Press

Möller, Joachim (2005): Wage Dispersion in Germany Compared to the US - Is there Evidence for Compression From Below?, ZEW Discussion Paper, Mannheim: Zentrum für Europäische Wirtschaftsforschung

Nickell, Stephen / Bell, Brian (1995): The Collapse in Demand for the Unskilled and Unemployment Across the OECD, in: Oxford Review of Economic Policy, Vol. II, No. I, pp. $40-62$

OECD (2004): Wage-setting Institutions and Outcomes, in: Employment Outlook 2004, Paris: OECD, pp. I27-I8I

OECD (1997): International Adult Literacy Survey, Paris: OECD

Siebert, Horst (1997): Labor Market Rigidities: At the Root of Unemployment in Europe, in: Journal of Economic Perspectives, Vol. II, No. 3, pp. 37-56

Tarshis, Lorie (1939): Changes in Real and Money Wages, in: Economic Journal, Vol. 49, No. I93, pp. I5O-I54

Welch, Finis (1999): Richard T. Ely Lecture - In Defense of Inequality, in: American Economic Review, Vol. 89, No. 2, pp. I-I7 